\title{
Improved Microstructural Homogeneity of Ni-BCY Cermets Membrane via High-Energy Milling
}

\author{
Hyejin Kim***, Kiyong Ahn****, Boyoung Kim*, Jongheun Lee**, and Yong-Chae Chung***, \\ Hae-Ryoung Kim*, and Jong-Ho Lee*,
}

*High-Temperature Energy Materials Research Center, Korea Institute of Science and Technology, Seoul 136-791, Korea

**Department of Materials Science and Engineering, Korea University, Seoul 136-701, Korea

***Department of Materials Science and Engineering, Hanyang University, Seoul 133-791, Korea

(Received August 31, 2012; Revised October 5, 2012; Accepted October 8, 2012)

고에너지 밀링을 통한 Ni-BaCe $\mathbf{B}_{0.9} \mathbf{Y}_{0.1} \mathbf{O}_{3-\delta}$ 서멧 멤브레인의 미세구조 균질성 향상

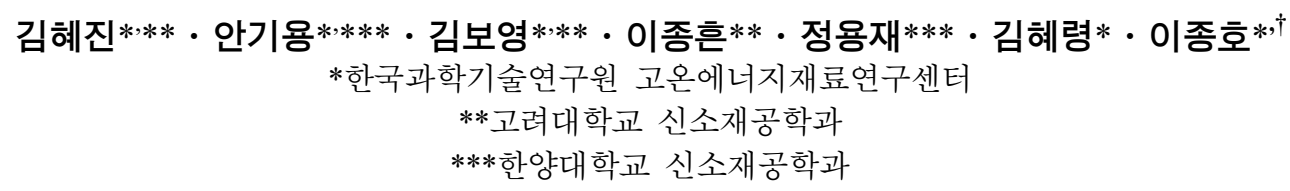

(2012년 8월 31일 접수 ; 2012년 10월 5일 수정 ; 2012년 10월 8일 채택)

\begin{abstract}
Hybridization of dense ceramic membranes for hydrogen separation with an electronically conductive metallic phase is normally utilized to enhance the hydrogen permeation flux and thereby to increase the production efficiency of hydrogen. In this study, we developed a nickel and proton conducting oxide $\left(\mathrm{BaCe}_{0.9} \mathrm{Y}_{0.1} \mathrm{O}_{3-\delta}\right.$ : $\mathrm{BCY}$ ) based cermet (ceramic-metal composites) membrane. Focused on the general criteria in that the hydrogen permeation properties of a cermet membrane depend on its microstructural features, such as the grain size and the homogeneity of the mix, we tried to optimize the microstructure of Ni-BCY cermets by controlling the fabrication condition. The Ni-BCY composite powder was synthesized via a solid-state reaction using $2 \mathrm{NiCO}_{3} \cdot 3 \mathrm{Ni}(\mathrm{OH})_{2} \cdot 4 \mathrm{H}_{2} \mathrm{O}, \mathrm{BaCeO}_{3}$, $\mathrm{CeO}_{2}$ and $\mathrm{Y}_{2} \mathrm{O}_{3}$ as a starting material. To optimize the mixing scale and homogeneity of the composite powder, we employed a high-energy milling process. With this high-energy milled composite powder, we could fabricate a fine-grained dense membrane with an excellent level of mixing homogeneity. This controlled Ni-BCY cermet membrane showed higher hydrogen permeability compared to uncontrolled Ni-BCY cermets created with a conventionally ball-milled composite powder.
\end{abstract}

Key words : Ni-BCY, Cermets, Hydrogen permeation, Membrane

\section{1. 서 론}

수소는 친환경적이고 풍부한 에너지자원으로 화석에너 지를 대체할 수 있는 미래형 에너지로 각광받고 있다. ${ }^{1)}$ 수소 연료전지의 주 연료로도 쓰이고 있는 수소는 대부 분 천연가스의 개질 작업을 통한 분리과정으로 생산되고 있다. 그러나 분리과정이 복잡하고 많은 비용이 발생하는 단점을 가지고 있어 최근에는 수소 분리막을 이용한 수 소 분리 공정이 주목 받고 있다. ${ }^{2,3)}$ 수소 분리막을 사용할 경우 기존 분리 공정에 비해 수소 전환 효율이 향상되고 에너지 소모는 감소되는 장점이 있다. 그러나 수소 분리

\footnotetext{
${ }^{\dagger}$ Corresponding author : Jong-Ho Lee

E-mail : jongho@kist.re.kr

Tel : +82-2-958-5532 Fax : +82-2-958-5529
}

막은 수소 분압, 농도 또는 온도 구배 등에 의해 수소를 분리하도록 되어있어 기본적으로 실제 고온, 고압작동 환 경에서의 높은 수소 투과성과 내구성을 갖춰야 한다. 수 소 분리막은 재료에 따라 고분자, 금속, 세라믹 분리막으 로 분류되고 있다. ${ }^{4,5)}$ 고분자 분리막은 다양한 산업과정 에서 이용되고 있으나 극한 화학적인 환경 또는 높은 온 도에서 사용될 수 없고, 고순도의 수소를 얻기 어렵다는 단점이 있다. 금속 분리막의 경우는 작동 온도 범위가 넓 고 수소 투과율이 높은 장점을 갖고 있다. 하지만 수소와 결합 시 나타나는 강한 취성으로 인하여 장기안정성에 문 제가 있고 값이 비싸다는 단점이 있다. ${ }^{5)}$ 세라믹 분리막의 경우는 수소가 전기화학적인 표면 반응에 의하여 분리막 의 연료 공급면에서 해리되고 수소이온으로 이온화되며 분리막을 투과하는 원리로 작동된다. 이때 수소이온은 분 
리막의 재료 내에서 수소 분압차에 의해 반대방향으로 이 동하게 되고 침투된 반대쪽에서 수소 분자를 형성하며 환 원된다. 이때 수소이온의 이동 시 전하중성 조건을 만족 시키기 위해 전자가 함께 이동하는 ambipolar 확산형태로 이동하게 된다. 이러한 세라믹 분리막은 $100 \%$ 수소 선택 성이 있는 무한한 분리 인자이므로 이차적인 기체의 정 제가 필요 없는 장점이 있으나 수소 투과율이 낮다는 단 점을 가진다. ${ }^{6-8)}$ 최근에는 세라믹 분리막에 비해 높은 수 소 투과율을 확보할 수 있으면서도 금속 분리막의 단점 인 내구성도 향상시킬 수 있는 세라믹과 금속의 복합체 인 서멧 재료가 주목 받고 있다. 일반적으로 서멧 분리막 은 수소이온 전도성 세라믹을 기반으로, 수소 비 투과성 인 $\mathrm{Ni}($ 니켈 $), \operatorname{Pt}($ 플래티늄) 및 투과성인 $\mathrm{Pd}$ (팔라듐 $), \mathrm{V}($ 바 나듐) 금속으로 구성되는데 이때 수소이온 전도성이 좋은 $\mathrm{BaCeO}_{3}$ 나 $\mathrm{BaZrO}_{3}$ 와 같은 이온-전자 혼합전도성 산화물 을 사용하면 고온 안정성이 우수하면서도 높은 수소 투 과도를 기대할 수 있다. 서멧 분리막의 경우는 세라믹 분 리막의 경우와 달리 수소이온과 전자가 각각 세라믹과 금 속상을 통해 이동할 수 있으므로 단일상을 통한 ambipolar 확산기구에 의한 확산보다 수소의 이동도를 훨씬 높일 수 있는 장점을 가지고 있다. ${ }^{9-11)}$

$$
\mathrm{J}_{\mathrm{H}_{2}}=-\left(\frac{\chi \mathrm{RT}}{4 F^{2} \mathrm{~L}} \int_{p_{\mathrm{H}_{2}}}^{p_{\mathrm{H}_{2}}^{\text {feep }}} \frac{\sigma_{\mathrm{OH}_{\mathrm{O}}} \sigma_{e^{\prime}}}{\sigma_{\mathrm{OH}_{\mathrm{O}}}+\sigma_{e^{\prime}}} d \ln p_{\mathrm{H}_{2}}+(1-\chi) \frac{\phi}{L} p^{\frac{1}{2}} p_{\mathrm{H}_{2}}\right)
$$

서멧 분리막을 통한 총 수소 유동은 Eq. (1) 과 같이 표 현되는데 이때 $\sigma_{i}$ 는 부분 전도도, $L$ 은 분리막의 두께, $F$ 는 Faraday 상수, $d \operatorname{lnPH} \mathrm{H}_{2}$ 은 수소의 산화물 분리막을 통 한 화학적 전위 변화, $\chi$ 은 산화물의 부피비, $\phi$ 은 $\mathrm{Ni}$ 의 수 소 유동도를 나타낸다. Eq. (1)에서 보듯이 수소의 유동량 은 분리막에서의 수소이온전도도와 전자전도도에 의존하 게 되는데 서멧 분리막의 경우 수소전도성이 좋은 세라 믹과 전자전도성이 좋은 금속상이 혼재해 있기에 어느 한 성분에 의한 이동제한을 덜 받게 되는 장점을 가진다.

한편 서멧 분리막에서 수소 선택성을 높이기 위해서는 가스상태로의 투과가 없는 치밀한 구조를 가져야 하며 우 수한 수소 이온 및 전자 전도성을 가져야 한다. 또한 고 온 작동환경에서의 안정성과 우수한 기계적/화학적 특성 이 요구된다. ${ }^{712)}$ 특히 서멧 분리막의 미세구조는 수소 침 투 유동을 규정할 수 있는 가장 중요한 요인으로서 재료의 치밀화와 금속과 세라믹간의 균일화가 전제되어야 하는데 특히 수소이온과 전자의 이동경로 상 유효면적을 극대화 하기 위해서는 아주 세라믹과 금속상간의 혼합 scale이 가 능한 아주 미세하여야 한다. ${ }^{7)}$ 본 연구에서는 이러한 우수 한 수소투과성을 가진 서멧 분리막을 제조하기 위해 수소 전도성은 물론 기계적인 특성이 우수하다고 알려진 ${ }^{10-14)}$ $\mathrm{BCY}\left(\mathrm{Ba}\left(\mathrm{Ce}_{0.9} \mathrm{Y}_{0.1}\right) \mathrm{O}_{3-\delta}\right)$ 와 전자 전도성이 우수한 $\mathrm{Ni}$ 을 복
합화한 분리막 조성을 선택하여 치밀질 분리막을 제조하 였다. 이때 보다 균일하고 치밀한 $\mathrm{Ni}-\mathrm{BCY}$ 서멧을 제조하 기 위해 본 연구에서는 합성된 복합분말의 혼합공정을 고 에너지 밀링을 통해 최적화하였고 이러한 공정변수 조절 에 따른 분리막의 치밀도와 미세구조 변화를 관찰하였다. 아울러 최적화된 공정을 이용해 제작된 치밀질 분리막의 수소투과 특성을 관찰하였다.

\section{2. 실험방법}

\subsection{Ni-BCY 서멧 분리막 제조}

$\mathrm{Ni}-\mathrm{BCY}$ 복합분말을 제조하기 위한 공정을 Fig. 1에 나 타내었다. 그림에서 보듯이 Ni-BCY 분말은 고상법에 의하 여 합성되었다. 시작재료로 $2 \mathrm{NiCO}_{3} \cdot 3 \mathrm{Ni}(\mathrm{OH})_{2} \cdot 4 \mathrm{H}_{2} \mathrm{O}$ (Sigma Aldrich, 99.9\%), $\mathrm{BaCO}_{3}$ (Cerac, 99.9\%), $\mathrm{CeO}_{2}$ (Cerac, 99.9\%) 와 $\mathrm{Y}_{2} \mathrm{O}_{3}$ (High purity chemical, 99.99\%)을 사용하였으며, 정해진 중량비로 칭량한 분말은 지르코니아 볼과 알코올 을 이용해 24시간 동안 습식 밀링하여 혼합하였다. BCY 의 단일상을 얻기 위하여 $1000^{\circ} \mathrm{C}$ 에서 10 시간 동안 공기 중에서 하소 하였으며, 하소 과정 중 형성된 응집체를 분 쇄하기 위하여 48시간 동안 다시 볼밀링 하였다. 한편 보 다 균질한 혼합체를 얻기 위하여 $600 \mathrm{rpm}$ 의 고에너지 밀 링을 10 시간 동안 추가적으로 시행하였다. 이렇게 얻어진

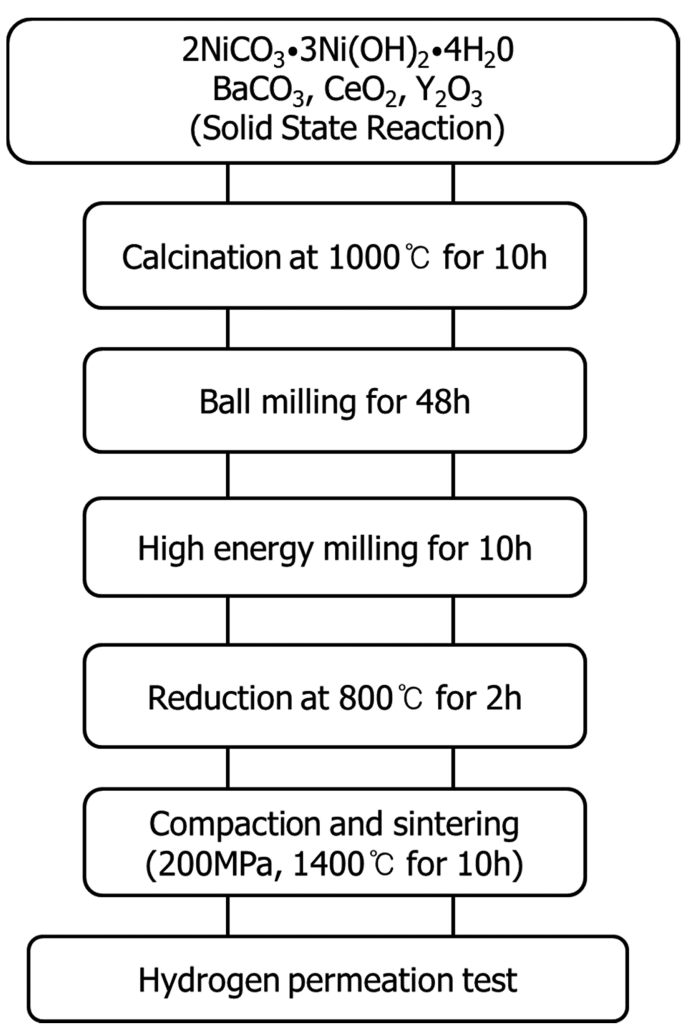

Fig. 1. Process flow for the fabrication of Ni-BCY hydrogen permeation membrane. 
분말들은 $\mathrm{NiO}-\mathrm{BCY}$ 상태로 $\mathrm{Ni}-\mathrm{BCY}$ 서멧 제조용 분말형 태로 얻기 위해 $800^{\circ} \mathrm{C}$ 에서 2 시간 동안 $4 \%$ 의 $\mathrm{H}_{2}$ 가 포함 된 $\mathrm{Ar}$ 분위기에서 환원하였다. 얻어진 $\mathrm{Ni}-\mathrm{BCY}$ 복합분말 은 수소투과실험을 위하여 $200 \mathrm{MPa}$ 의 압력으로 Pellet 형 태로 일축가압 성형한 후 $1400^{\circ} \mathrm{C}$ 에서 10 시간 동안 소결하 였다. 이때 소결과 냉각과정 중 Ni-BCY 서멧 멤브레인의 표면에서 산화막이 형성되는 것을 방지하기 위하여 소결 로는 계속 환원 분위기를 유지하였다.

\subsection{Ni-BCY 분리막의 특성평가}

$\mathrm{Ni}$ 와 $\mathrm{BCY}$ 복합상으로 이루어진 서멧의 상 분석은 $\mathrm{X}$ ray 회절 (PW3830, PANalytical, Netherlands) 을 통하여 실시하였다. Ni-BCY 복합체의 소결 거동은 Dilatometer (DIL 402C, NETZSCH, Germany)로 분석하였으며 SEM의 후면 산란 전자 이미지 (BSE image)로 각 제조 단계별 시 편들의 미세구조를 확인하였다. 수소 투과 실험을 위해 제조한 pellet 형태의 시편은 이론밀도가 $97 \%$ 이상이고 직경이 $17 \mathrm{~mm}$, 두께가 $0.38 \mathrm{~mm}$ 이었다. 이때 제조된 시 편의 표면은 $\mathrm{SiC}$ 페이퍼로 평탄하게 연마하였으며 Fig. 2 에 나타낸 것처럼 투과도 측정 장비에 장착하였다. 투과 도 측정을 위해 멤브레인 양단의 수소분압을 달리하기 위 해 세라믹과 유리의 화합물 형태인 복합체 가스켓을 밀 봉재로 사용하였다. 이때 밀봉은 유리가 유동성을 가지는 $760^{\circ} \mathrm{C}$ 부근에서 일정한 압력을 가함으로써 이루어지는데 이러한 밀봉방법을 통해 투과장치 외부로는 물론 멤브레 인 양단의 가스혼합을 차단할 수 있었다. 수소 투과 실험 은 $650 \sim 800^{\circ} \mathrm{C}$ 구간에서 수행하였으며 이때 수소가 투과 되어 나오는 면 (sweep side) 쪽으로는 $100 \mathrm{ppm}$ 의 $\mathrm{H}_{2}$ 가 혼합된 질소를 총 $100 \mathrm{sccm}$ 의 유속으로 흘려주었으며, 수 소 투과가 시작되는 연료 공급 면 (feed side) 쪽에는 총 $100 \mathrm{sccm}$ 의 유속으로 $4 \% \mathrm{H}_{2}$ 가 섞인 $\mathrm{He}$ 가스를 흘려주었 다. 모든 가스 흐름은 질량유량계 (Mass Flow Controller)

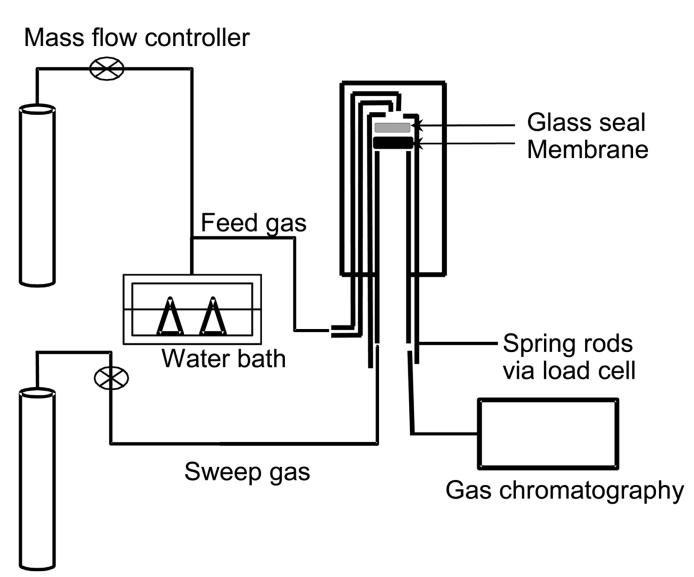

Fig. 2. Schematic set up for electrochemical characterization of gas permeation membrane.
에 의하여 조절하였으며 투과된 수소기체의 양은 가스 크 로마토그래프 (CP-4900 Micro GC, Varian) 로 측정하였다. 이때 시편에 잔류하는 미세 기공들 또는 완전하지 않은 밀봉에 의하여 발생되는 가스의 누출은 $\mathrm{He}$ 를 이용하여 확인하였다.

\section{3. 결과 및 고찰}

Fig. 3은 Fig. 1에 제시된 공정단계별 Ni-BCY 분말에 대한 $\mathrm{X}$ 선 회절 분석 결과이다. Fig. 3(a)에서 보듯이 고 상반응법으로 합성된 분말은 $1000^{\circ} \mathrm{C}$ 하소 후 $\mathrm{BCY}$ 와 $\mathrm{NiO}$ 복합상으로 잘 형성되었으며 $\mathrm{BaCO}_{3}$ 나 $\mathrm{CeO}_{2}$ 와 같은 2차 상의 형성은 관찰되지 않았다. 한편 하소 후 분말을 $800^{\circ} \mathrm{C}$ 에서 2시간 동안 환원한 결과 Fig. $3(\mathrm{~b})$ 에서 보듯이 $\mathrm{NiO}$ 가 $\mathrm{Ni}$ 로 모두 환원된 $\mathrm{Ni}-\mathrm{BCY}$ 형태의 복합 분말을 얻을 수 있었으며 이를 멤브레인 제조와 동일한 소결조건 인 $1400^{\circ} \mathrm{C}$, 환원분위기에서 10 시간 추가 열처리 한 결과 Fig. 3(c)에서 보듯이 2차상 없는 균질한 Ni-BCY 복합상 을 얻을 수 있었다.

보다 균질한 $\mathrm{Ni}-\mathrm{BCY}$ 서멧 제조를 위해 고에너지 밀링 을 추가한 Ni-BCY 복합체 분말의 특성을 관찰하였다. 고 에너지 밀링은 연성을 가진 재료와 취성을 가진 세라믹 재료 사이의 혼합에 이점이 있는 공정으로 알려져 주로 연성을 가진 금속과 취성을 갖고 있는 세라믹을 혼합할 때 많이 사용되어 왔으나 ${ }^{15,16)}$ 본 연구에서는 상대적으로 연한 $\mathrm{NiO}$ 와 $\mathrm{BCY}$ 의 혼합에도 효과가 있을 것으로 기대 하고 이를 적용하였다. Fig. 4에는 고에너지 밀링을 적용 하기 전과 후의 $\mathrm{NiO}-\mathrm{BCY}$ 분말의 미세구조결과를 비교해 놓았다. 그림의 결과에서 보면 예상과 같이 고에너지 밀 링을 통해 연성의 $\mathrm{NiO}$ 입자위에 취성을 가진 $\mathrm{BCY}$ 산화

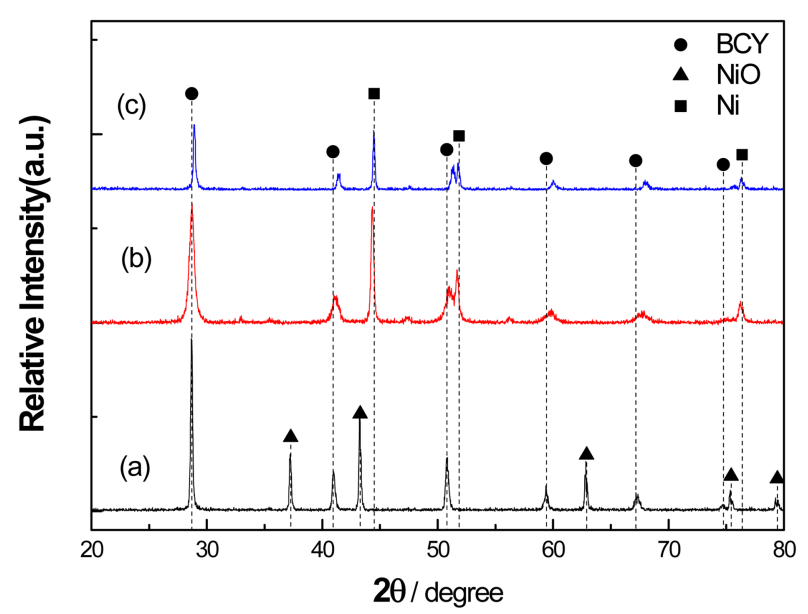

Fig. 3. X-ray diffraction pattern of (a) NiO-BCY after calcination at $1000^{\circ} \mathrm{C}$ for $10 \mathrm{~h},(\mathrm{~b}) \mathrm{Ni}-\mathrm{BCY}$ after reduction at $800^{\circ} \mathrm{C}$ for $2 \mathrm{~h}$, and (c) Ni-BCY after sintering at $1400^{\circ} \mathrm{C}$ for $10 \mathrm{~h}$. 

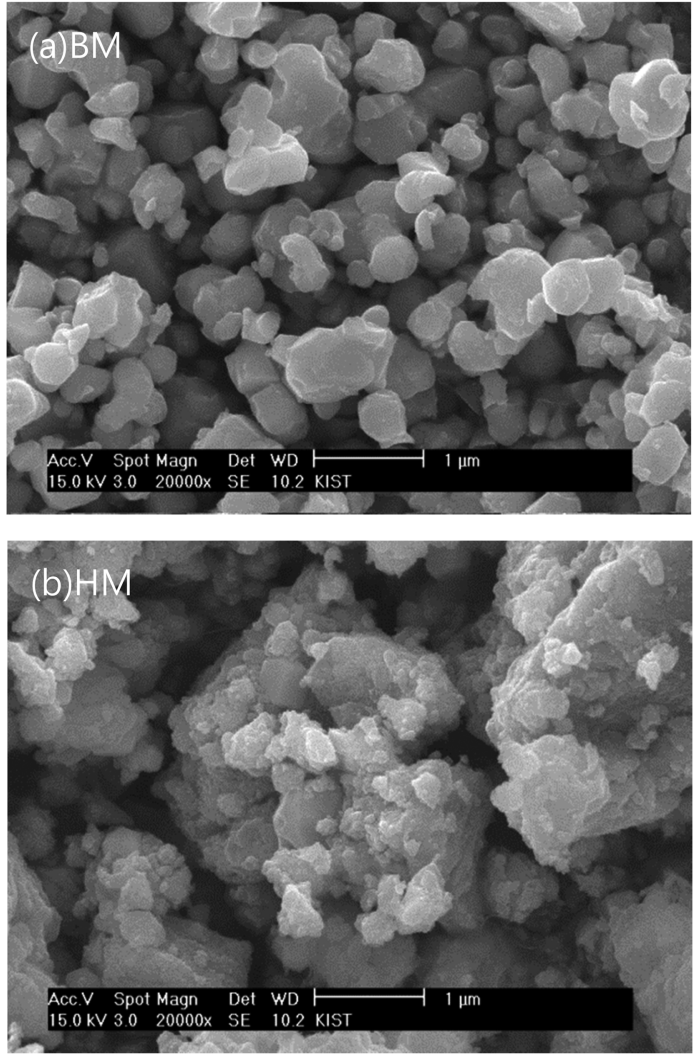

Fig. 4. SEM image of NiO-BCY composite powder after (a) ball milling $(\mathrm{BM})$ process and (b) ball milling (BM) and high energy milling (HM).

물들이 얇게 코팅된 형태로 존재하고 있었으며 이는 $\mathrm{EDS}$ 분석을 통해 확인할 수 있었다.

한편 고에너지 밀링을 거친 $\mathrm{Ni}-\mathrm{BCY}$ 복합분말과 그렇 지 않은 복합분말의 소결 거동을 관찰한 결과 Fig. 5의 Dilatometer 결과에서 보듯이 두 경우 수축거동에서 큰 차 이를 보였다. 먼저 Fig. 5(a)와 (c)의 결과에서 보면 $1000^{\circ} \mathrm{C}$ 부근에서 수축이 시작되는 단일상 $\mathrm{BCY}$ 에 비해 일반적인 볼밀링만 거친 분말의 경우 $1100^{\circ} \mathrm{C}$ 부터 수축이 시작되어 수축이 시작되는 시점에 있어서는 차이가 나나 전반적인 수축거동에는 크게 차이가 없었다. 이는 단순한 볼밀링 만으로는 $\mathrm{Ni}$ 와 $\mathrm{BCY}$ 분말을 미세하게 분쇄하는 데 한계가 있으며 또한 복합체내의 혼합균일도도 떨어져 충분한 수축률을 얻을 수 없었기 때문으로 보인다. 반면 고에너지 밀링을 추가한 Ni-BCY 복합분말 (Fig. 5(b))의 경우에는 초기 수축은 $\mathrm{Ni}$ 표면에 분포한 $\mathrm{BCY}$ 상에 의해 제어되어 단일상 $\mathrm{BCY}$ 와 유사한 거동을 보이나 $1200^{\circ} \mathrm{C}$ 근처부터 $\mathrm{Ni}$ 상의 연결도가 생기며 소결이 촉진되면서 최 종 수축률이 $16 \%$ 로 증가함을 볼 수 있다. 이러한 수축률 의 증가는 고에너지 밀링에 의하여 미세하면서도 균일하 게 분포된 $\mathrm{Ni}$ 분말에 의해 소결이 촉진됨에 따른 것이며 이와 같은 결과는 Fig. 6의 미세구조 관찰을 통하여도 확

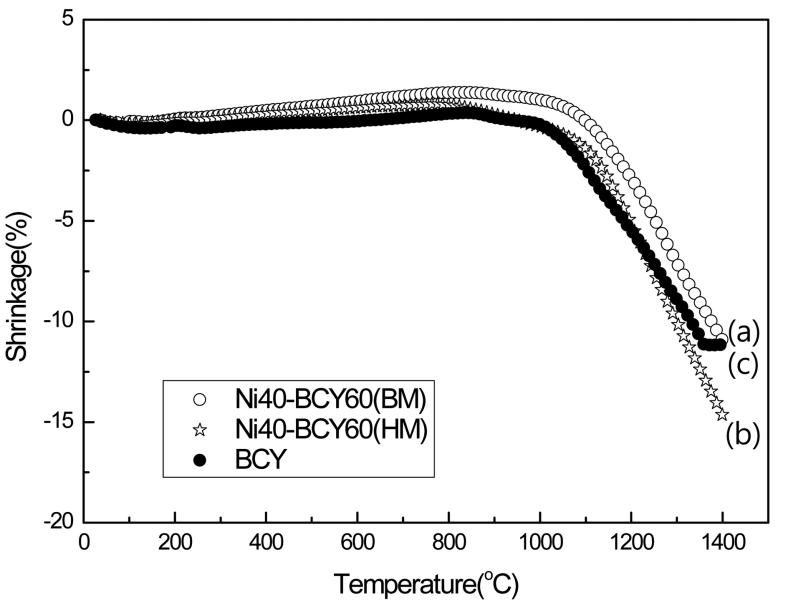

Fig. 5. Shrinkage curves (a) of the Ni-BCY after ball milling (BM) process, (b) after ball milling (BM) and high energy milling (HM), and (c) original BCY powder.
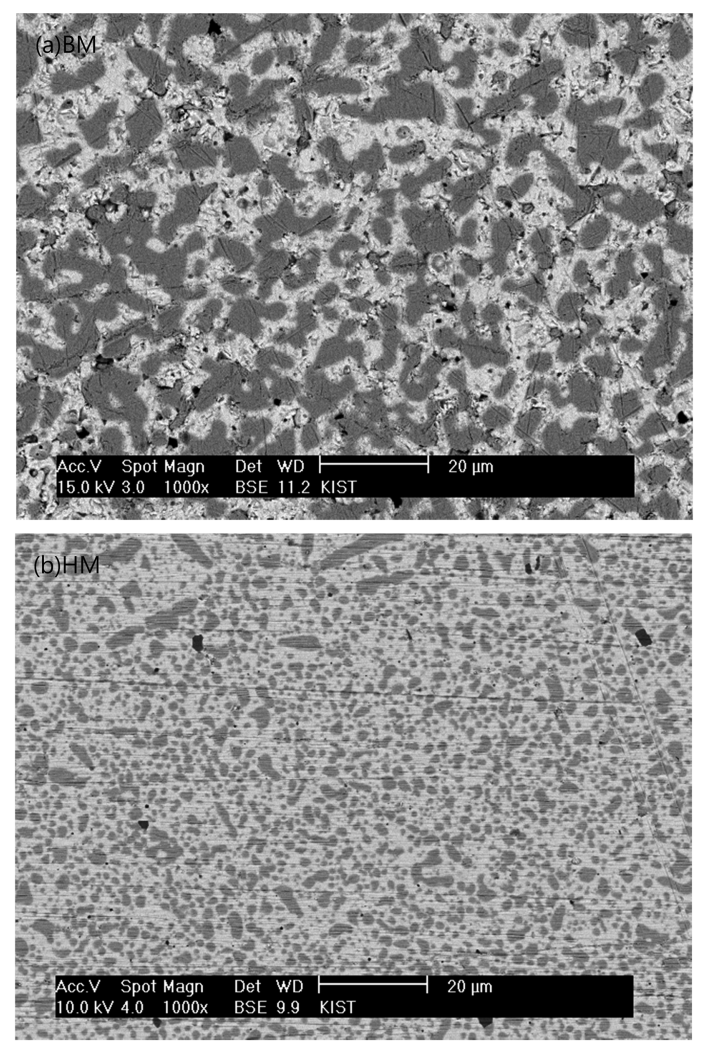

Fig. 6. The back scattered electron images of the Ni-BCY membrane after sintering at $1400^{\circ} \mathrm{C}$ for $10 \mathrm{~h}$ : (a) ball milling (BM) process and (b) ball milling (BM) and high energy milling (HM).

인할 수 있었다.

Fig. 6은 고에너지 밀링을 한 Ni-BCY 복합분말과 하지 않은 복합분말을 가지고 공히 $1400^{\circ} \mathrm{C}$ 에서 10 시간 동안 소결한 후 관찰한 $\mathrm{Ni}-\mathrm{BCY}$ 소결체 단면의 후면 산란 전 자 이미지 이다. 그림에 나타낸 이미지에서 회색은 $\mathrm{Ni}$ 상 


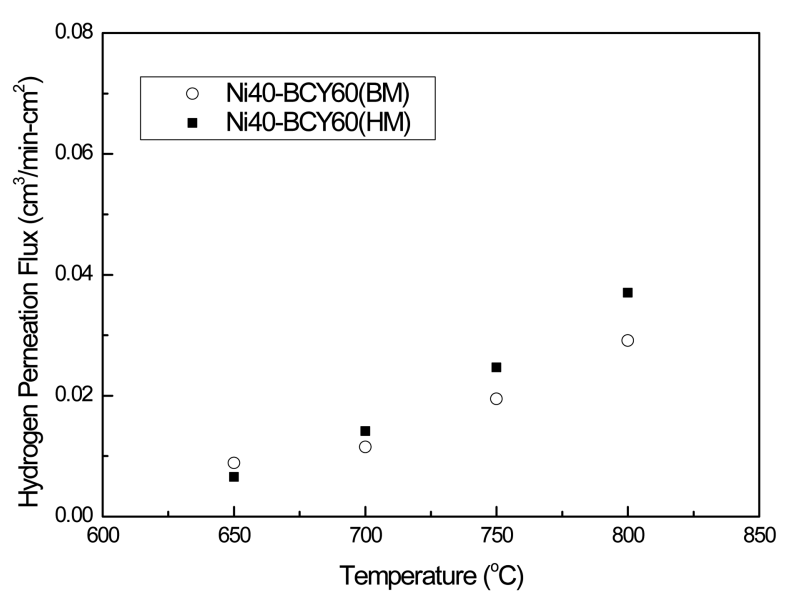

Fig. 7. Comparison of hydrogen permeation flux of the $\mathrm{Ni}$ BCY membrane (thickness $\approx 380 \mu \mathrm{m}$ ).

을, 흰색은 $\mathrm{BCY}$ 상을, 그리고 검은색은 기공을 각각 나 타낸다. 앞서 서론에서 밝혔듯이 서멧 수소 분리막의 경 우 높은 수소 투과율을 위해서 금속과 세라믹상이 미세 하고 균일하게 분포되어야 한다. 또한 고순도의 수소를 침투시키기 위하여 개기공이 없는 치밀한 분리막을 얻는 것이 매우 중요하다. 이러한 관점에서 Fig. 6의 결과를 살 펴보면 고에너지 밀링을 거치지 않은 복합체의 경우 소 결과정을 거치면서 $\mathrm{Ni}$ 상의 응집이 일어나 거대한 응집 체들이 분리막 전면에 분포되어 있는 것을 확인할 수 있 다. 반면 고에너지 밀링을 거친 $\mathrm{Ni}-\mathrm{BCY}$ 의 경우 $\mathrm{Ni}$ 상이 응집되지 않고 비교적 미세하고 균일하게 분포 되어있는 것을 확인할 수 있었다.

이와 같이 치밀도는 물론 입자의 크기와 균질도 면에 서 차이가 나는 두종류 서멧 멤브레인에 대하여 미세구조 의 차이에 따른 수소투과율 차이를 분석해 보았다. Fig. 7 은 앞서 소개한 Fig. 2의 수소투과측정장치를 이용해 측 정한 수소투과도 측정결과이다. 그림의 결과에서 보면 두 경우 모두 온도가 낮아지며 수소투과율은 감소하였으며 두 분리막 간 투과성능 차이는 온도가 낮아지며 감소하 였다. 그러나 전반적으로는 미세구조 관찰결과로부터 예 상해 볼 수 있듯이 더 치밀하고 균일한 미세구조를 가진 고에너지 밀링을 실시한 분리막에서의 수소투과율이 상 대적으로 더 높게 나타났다. 이상의 결과로부터 알 수 있 듯이 서멧 멤브레인의 수소투과 성능은 서멧을 구성하는 입자의 크기 및 균질도에 의해 크게 영향을 받으며 본 연 구에서 채택한 고에너지 밀링의 경우 복합분말의 미세화 와 혼합균일도를 향상시켜 서멧 멤브레인의 미세구조를 개선하는데 효과적임을 알 수 있었다.

\section{4. 결 론}

고상법으로 합성한 $\mathrm{Ni-BCY}$ 복합분말을 각각 볼밀링과
고에너지 밀링으로 분쇄 및 혼합 한 후 각각의 분말특성 과 소결특성을 관찰하였다. $\mathrm{XRD}$ 를 통한 상분석 결과 두 경우 모두 이차상 생성 없이 균질한 Ni-BCY 상을 가지 고 있었으며 Dilatometer을 이용한 소결특성을 관찰한 결 과 고에너지 밀링을 거친 복합분말의 소결특성이 치밀질 멤브레인을 제조하는데 더 효과적임을 알 수 있었다. 한 편 이들 복합분말을 가지고 제조한 치밀질 $\mathrm{Ni}-\mathrm{BCY}$ 멤브 레인의 미세구조를 관찰한 결과 고에너지 밀링을 거쳐 제 조된 서멧 분리막의 경우 처음 예상했던 바와 같이 미세 구조가 더 미세하고 균질하며 두 상의 혼합상태 또한 우 수하게 나타났다. 이러한 미세구조적인 장점으로 인해 고 에너지 밀링으로 제조된 Ni-BCY 분리막의 수소투과특성 이 볼밀링만을 거쳐 제조된 분리막에 비해 측정온도 대 부분의 영역 $\left(700 \sim 800^{\circ} \mathrm{C}\right)$ 에서 더 높은 투과율을 보였 다. 이러한 결과로부터 본 연구에서는 고에너지 밀링을 통한 추가분쇄 및 혼합 과정이 $\mathrm{Ni}$ 상의 응집 억제는 물 론 각 상의 균질한 분포에 기여해 수소투과에 유리한 서 멧구조를 형성시킴을 알 수 있었다.

\section{Acknowledgment}

본 연구는 한국과학기술연구원 기관고유사업 및 한국 연구재단의 기반형 녹색기술 융합연구사업으로 지원되었 으며 이에 감사 드립니다.

\section{REFERENCES}

1. International Atomic Energy Agency (IAEA), "Hydrogen as an Energy Carrier and its Production by Nuclear Power", Reported by IAEA-TECDOC-1085, (1999).

2. US Department of Energy (US DOE) and US Department of Transpotation (US DOT), "Hydrogen Posture Plan", Reported by DOE and DOT (2006).

3. D. Jack, D. Anderson, C. Evenson, and D. Waters, "Hydrogen Separation Membrane Application", Eltron Research \& Development (2009).

4. International Energy Agency (IEA), "Prospects for Hydrogen and Fuel Cells", Reported by the Secretariat of IEA (2005).

5. J. W. Phair, and S. P. S. Badwal, "Review of Proton Conductors for Hydrogen Separation", Ionics, 12 [2] 103-15 (2006).

6. S. J. Song, E. D. Wachsman, J. Rhodes, S. E. Dorris, and U. Balachandran, "Hydrogen Permeability of $\mathrm{SrCe}_{1 \mathrm{x}} \mathrm{M}_{\mathrm{x}} \mathrm{O}_{3-\delta}$ $(\mathrm{x}=0.05, \mathrm{M}=\mathrm{Eu}, \mathrm{Sm})$, , Solid State Ionics, 167 [1-2] 99105 (2004).

7. S. J. Song, E. D. Wachsman, J. Rhodes, H. S. Yoon, G. Zhang, K. H. Lee, S. E. Dorris, and U. Balachandran, "Hydrogen Permeability and Effect of Microstructure on Mixed Protonic-Electronic Conducting Eu-doped Strontium Cerate," J. Mater. Sci., 40 4061-66 (2005). 
8. J. Guan, S. E. Dorris, U. Balachandran, and M. Liu, "Transport Properties of $\mathrm{SrCe}_{0.95} \mathrm{Y}_{0.05} \mathrm{O}_{3-\delta}$ and its Application for Hydrogen Separation", Solid State Ionics, 110 [3-4] 303-10 (1998).

9. T. Hibino, K Mizutani, T. Yajima, and H. Iwahara "Evaluation of Proton Conductivity in $\mathrm{SrCeO}_{3}, \mathrm{BaCeO}_{3}, \mathrm{CaZrO}_{3}$ and $\mathrm{SrZrO}_{3}$ by Temperature Programmed Desorption Method", Solid State Ionics, 57 [3-4] 303-6 (1992).

10. S. J. Song, T.H. Lee, E.D. Wachsman, L. Chen, S.E. Dorris, and U. Balachandran, "Defect Structure and Transport Properties of $\mathrm{Ni}-\mathrm{SrCeO}_{3-\delta}$ Cermet for Hydrogen Separation Membrane", J. Electrochem. Soc., 152 [11] J 125 (2005).

11. C. Zuo, T.H. Lee, S.-J. Song, L. Chen, S.E. Dorris, U. Balachandran, and M. Liu, "Hydrogen Permeation and Chemical Stability of Cermet $\left[\mathrm{Ni}-\mathrm{Ba}\left(\mathrm{Zr}_{0.8-\mathrm{x}} \mathrm{Ce}_{\mathrm{x}} \mathrm{Y}_{0.2}\right) \mathrm{O}_{3}\right]$ Membranes", Electrochem. Solid State Lett., 8 [12] J 35 (2005).

12. S. J. Song, E. D. Wachsman, J. Rhodes, H. S. Yoon, K. H.
Lee, G. Zhang, S.E. Dorris, U. BalachandranS. J. Song, E. D. Wachsman, S. E. Dorris, and U. Balachandran, "Defect Chemistry Modeling of High-Temperature Proton-Conducting Cerates," Solid State Ionics, 149 [1-2] 1-10 (2002).

13. S. J. Song, E. D. Wachsman, S. E. Dorris, and U. Balachandran, "Electrical Properties of p-type Electronic Defects in the Protonic Conductor $\mathrm{SrCe}_{0.95} \mathrm{Eu}_{0.05} \mathrm{O}_{3-\delta}$," $J$. Electrochem. Soc., 150 A790-A795 (2003).

14. H. Iwahara, "Hydrogen Pumps using Proton-conducting Ceramics and their Applications," Solid State Ionics, 125 271-78 (1999).

15. C. Suryanarayana, "Mechanical Alloying and Milling", Progress in Materials Science, 46 1-184 (2001)

16. T.A.G. Restivo, S.R.H. de Mello-Castanho, "Nickel-zirconia Cermet Processing by Mechanical Alloying for Solid Oxide Fuel Cell Anodes," J. Power Sources, 185 1262-66 (2008). 